\title{
MODERN PARADIGM OF SPORTS POLICY AS IDEOLOGY OF HEALTHY SOCIETY
}

\author{
Yaroslav Leonov ${ }^{1}$
}

\begin{abstract}
The purpose of the article is to deepen general theoretical concepts to ensure a healthy society and to form an actual sports policy. The article examines the role of the state in the formation of the modern stage of society's development and the need to create a modern paradigm of sports policy, which should be aimed at a person, namely, to strengthen human capital, which is the basis of any social system. Results. Undoubtedly, the degree of development of human capital determines the competitiveness of the labour force and the development of the country's economy, that is, it is the high level of the demographic resource that is the determining factor. This resource is formed from quantitative and qualitative characteristics: economic, social, and cultural capabilities of the country's population. Any loss of human resources, regardless of the reason for it, is not only an indicator of internal political instability but also a problem of a geopolitical scale. This is what leads to the destabilization of the situation in society, weakening it, which in turn can pose a great threat to all mankind. The categories "social capital" and "human capital" are analyzed. It is determined that in the process of formation and development of human capital, it is necessary to take into account the role of social capital in it. It is noted that in the totality of the most common components of human capital, the main place should be occupied by the "capital of health", since it is health, together with education, that determines a person's ability to fulfill basic social and economic functions, his or her active participation in the process of achieving not only his or her own well-being but the competitiveness of the national economy as well. Thus, the problem of maintaining the health of the nation for any state is one of the most important. Health is a natural value in life, both individual and social. At the same time, the essence of the value of health lies in the fact that only with its existence a person can fully realize his or her potential and feel the fullness of life. Thus, it becomes clear that it is health that is the core of human capital because existence is impossible without it. Achieving these goals involves recognizing the inextricable link between health, community development and poverty reduction. Health promotion is fundamental in mobilizing society to achieve this goal through the necessary advocacy measures and appropriate strategies. It is necessary to note that the term "Physical activity" is defined as any bodily movement produced by skeletal muscles and which requires energy. The problem of insufficient physical activity indicates that an active lifestyle is critical for health but in our modern world this is an increasingly difficult task. Moreover, physical inactivity is not only a health problem; it also carries huge financial costs for health care and the costs of declining productivity. Note that at the present stage of development of society, insufficient physical activity is one of the main risk factors for death in the world, while its level is growing in many countries, which increases the costs of non-infectious diseases and affects the general health of the population. People who are not physically active enough have a $20 \%-30 \%$ higher risk of mortality compared to those who lead an active lifestyle. One in four adult men in the world is not physically active enough, and more than $80 \%$ of adolescents lack physical activity. The primary responsibility for preventing physical inactivity-related illnesses rests with the national government, which has a central role to play in these activities, but engagement from all sectors of society, international cooperation and joint action are key elements of success. Accordingly, if at the global level there is an understanding that a person can be healthy only with regular physical activity, one should accept this as an indisputable fact and bring it to the consciousness of every person as a truth. Value/originality. Therefore, it is obvious that this task should be solved at the state level through the development and implementation of national sports policy and providing conditions for the development of the sports industry because a healthy person is the basis of a strong, competitive and prosperous country.
\end{abstract}

Key words: sports capital, human capital, social capital, physical activity, health, sports industry, strategic development, government policy, national economy.

JEL Classification: P12, J24, 110, 128

Corresponding author:

${ }^{1}$ Kharkiv State Academy of Physical Culture, Ukraine.

E-mail: leonov.yaroslav.2017@gmail.com

ORCID: https://orcid.org/0000-0001-8837-5744 


\section{Introduction}

It is well known that an irresistible striving for knowledge and, as a result, the search for truth is inherent in every person by nature. The path to truth is not easy, as there are many obstacles to overcome. However, at the same time, the spiritual value is also necessary for every person.

At the same time, any truth is initially perceived by people with strong resistance because this is their psychology. However, as soon as the truth manifests itself and becomes an indisputable fact, it attracts the attention of more and more people. Therefore, truth should be at the core of any paradigm.

In the modern world, a paradigm is a set of scientific views and fundamental ideas in any area of knowledge, which at a certain historical stage in the development of science are accepted by representatives of the "scientific community" as real and determine the direction of all subsequent research. In other words, it embodies the undoubted, generally accepted idea about phenomena, processes and events in the studied area of knowledge (Sukharev, Diadichev, 2012).

When replacing each other, the paradigms testify to a broader knowledge of the world. The creation of a new paradigm allows not only to gain knowledge but also to influence a change in the worldview. From the point of view of philosophy, the concept of a paradigm is a model of any kind of human activity, taken as a model. In ancient times, the concept of a paradigm was used to characterize ideas - "samples" of the creation of the world (Kirilenko, Shevtcov, 2010). The scientific philosophers (Immanuel Kant, Auguste Comte, Martin Heidegger, Carl Gustav Jung etc.) created paradigms based on the knowledge of human existence. In turn, all these paradigms corresponded to the level of historical development of their period.

The current stage of development of society requires the creation of a new paradigm, which should be aimed at a person, namely, the formation of human capital, which is the basis of any social system. The degree of development of human capital determines the competitiveness of the labour force and the development of the country's economy, that is, it is the high level of the demographic resource that is the determining factor. This resource is formed from quantitative and qualitative characteristics: economic, social, and cultural capabilities of the country's population. Any loss of human resources, regardless of the reason for it, is not only an indicator of internal political instability, but also a problem of a geopolitical scale. This is what leads to the destabilization of the situation in society, weakening it, which in turn can become a great threat to all mankind.

\section{Evolution of sports policy development}

The general theory of economic growth and development of society can be observed in the works of economists of the 19th century: W. Petty, A. Smith, D. Ricardo, K. Marx, W. Thompson, M. TuhanBaranovskyi, M. Kondratiev, J. Schumpeter etc. The theory of human capital was formed in the second half of the 20th century and consolidated its position in economics thanks to the work of G. Becker, T. Schultz, and J. Mincer. For example, according to the theory of G. Becker, human capital is a stock of knowledge, skills, motivation available to everyone. Investments in human capital can be education, gaining work experience, health care and information retrieval. In addition, G. Becker made a kind of combination of economic and sociological views on human capital and its elements (Becker, 1975). However, the question of the impact of physical activity on the quality of human capital remains relevant.

Considering the main aspects of the formation and functioning of human capital, it is necessary to take into account the importance of social capital in this process. The most significant contribution to the development of the concept of social capital was made by the French sociologist Pierre Bourdieu and the American sociologist James Coleman, who in their works conducted a deep theoretical analysis of the category of "social capital", examined the relationship between economic and social capital and substantiated the role of society, family and group in the process of accumulation of social capital. Their works indicate that when analyzing the factors influencing the process of formation and development of human capital, it is also necessary to take into account the role of social capital in it (Mikhaileva, 2016).

In the aggregate of the most common components of human capital, the main place is occupied by "health capital", since it is health, together with education, that determines a person's ability to fully fulfill basic social and economic functions, his or her active participation in the process of achieving not only his or her own well-being, but also the competitiveness of the national economy. So, the problem of preserving the health of the nation for any state is one of the most important.

The studies of famous scientists can confirm this. For example, G. Becker drew an analogy between investing in health capital and investing in other forms of human capital (education capital, training capital, etc.): "One way to invest in human capital is to improve emotional and physical health... Health, like knowledge, can be improved in different ways. Reducing the mortality of people of working age can improve the prospects of earning money by extending the period during which a person is able to engage in paid work" (Becker, 1975).

In turn, the American economist Michael Grossman argued that "health capital is different from other forms 
of human capital. A person's knowledge reserves affect his or her productivity and his or her health stock determines the total amount of time he or she can spend on income" (Grossman, 1972). He conducted an empirical study, in which he considered "health as a strong capital that gives access to a full life", pointing out that "health depreciates with age and can be increased through investment" (Grossman, 2000). Thus, M. Grossman's model was based on the understanding that human behavior should be similar to an investor who makes a rational choice between what he or she is willing to sacrifice at present to improve their health, to increase their life expectancy in the future.

The health component is becoming paramount in modern human capital research. For example, Forrester S.V. believes: "The basis of the functioning of human capital at the level of the individual, team (group) and at the level of society (state) is the capital of health. Investing in health, on the one hand, determines the very possibility of formation and functioning of human capital, on the other hand, increases its duration. They entail the growth of social production and personal incomes of citizens, have a positive impact on the pace of socio-economic development of the country" (Forrester, Verevkina, 2016; Diogenes Laërtius, 1986; Ushakova, Nalivaiko, Vorontcov, 2017).

So it is the "capital of health" that is the basis of human capital, since for many centuries health has been one of the most important phenomena of life that characterizes the quality of human life. Different stages of development of society give different characteristics to the concept of health. This is due to certain sociocultural conditions in which the formation of specific types of worldviews took place. Understanding of the concept of health is still in the center of attention of researchers from various scientific fields of knowledge. It reflects the fundamental aspects of human life, which makes it necessary to apply an interdisciplinary approach to the consideration of this concept.

Attempts to define the essence of health were made several centuries before the common era by ancient Greek thinkers and philosophers. So, for example, Hecato and Chryssip noted that health "has predominant value" and "care must be taken about health". In turn, Panethius and Posidonius believed that "health is necessary for happiness". According to the teachings of Pythagoras, "health is a virtue, the preservation of the image, and disease is its destruction". Aristotle designated health as "bodily good, and good is happiness" (Bagnovskaia, 2017).

The modern era was marked by works in the field of philosophy, medicine, economics, sociology, pedagogy, ecology, which consider the essence of the concept of "health", its various aspects and social significance, as well as approaches to its study. According to the latest research by scientists, the health period is characterized as:
- initially (genetically) given, and then consciously controlled: optimal interaction of internal structures and processes (functions) of the organism, its material and energetic nature; resistance to external aggressive influences; optimal interaction with complementary systems and environments of the surrounding world (Boiko, 2014);

- harmony of all its components: cosmic, biological, mental (spiritual), and social (Zahalna teoriia zdorovia ta zdoroviazberezhennia, 2017);

- an integrative characteristic of a person, which encompasses both his or her inner world (integral, multidimensional, dynamic state), and all the originality of relationships with the environment and includes physical, mental, social and moral and spiritual aspects that provide the level of social activity necessary for society, the maximum duration of active life; as a state of balance, a balance between the adaptive capabilities of a person and constantly changing environmental conditions (Statut Vsesvitnoi orhanizatsii okhorony zdorovia);

- dynamic state of preservation and development of psychophysiological functions of an individual, optimal performance and social activity with a maximum life expectancy (Health promotion and healthy lifestyles).

By the concept of "health", the World Health Organization (WHO) means a state of complete physical, mental and social well-being, and not just the absence of disease and physical defects (Global action plan for the prevention and control of noncommunicable diseases). So, health is a natural value in life, both individual and social. The essence of the value of health lies in the fact that only with its presence a person can fully realize his or her potential and live big.

Thus, it becomes clear that it is health that is the core of human capital because without it the existence of other components is impossible, and there is no more important national task than improving the health of the population.

\section{Modern paradigms of sports policy}

The current state of human health is at an insufficient level and this fact negatively affects the world community, requiring the adoption of non-standard management decisions. The issue must be addressed through the development, implementation and global practice of human health promotion.

Organizational support (strategies, models and methods) of health promotion should focus on all age groups of the population, risk factors, diseases and living conditions and not be limited to the problem of health only. In addition, measures to improve education, community development, policies, laws and regulations are just as important for the prevention of infectious diseases as for addressing the main risk factors for noninfectious diseases (malnutrition, tobacco use, 
sedentary lifestyle and alcohol abuse), and to prevent injury, violence and mental illness.

Achieving these goals involves recognizing the inextricable link between health, community development and poverty reduction. Health promotion is fundamental in mobilizing society to achieve this goal through the necessary advocacy and appropriate strategies (Hippocrates, 1936; Kondrashov, 2010).

The question arises: what is it necessary to build a modern paradigm on if it is pivoted on a healthy person?

To answer this question, first of all, it is necessary to go several centuries back and turn to the teachings of Hippocrates, the famous ancient Greek physician and philosopher, who is still considered the "father of medicine".

The ideology of Hippocrates indicates that a healthy person should not be based on treatment but on the prevention and prophylaxis of diseases, in particular, leading a healthy lifestyle. This opinion is confirmed by a quote from the book "On the Nature of Man": "But when diseases of all kinds are born at the same time, then, without a doubt, the cause of each is the way of life for everyone and treatment should be taken which stands against the cause of the disease ... and changes the way of life, because it is obvious that the kind of life that a person is used to live either in full, or in part, or in one thing, does not correspond to him or her at all. And having learned about this, he or she must change it..." (Hippocrates, 1936).

It is worth focusing on the fact that, speaking about a healthy lifestyle, Hippocrates paid attention to proper nutrition, especially the need for regular physical activity. This statement is formulated in the book "On a healthy lifestyle": "For those who are engaged in gymnastics, it is useful to run and wrestle in winter, and in summer to wrestle a little bit and not to run at all, but to walk a lot in the cool. Those who get tired of running should wrestle and those who get tired of wrestling should run because in this way any part of the body that is tired of work can best of all warm up, strengthen and rest" (Hippocrates, 1936). Here is the well-known aphorism of Hippocrates: "gymnastics, physical exercises, walking must be firmly established in the everyday life of everyone who wants to maintain efficiency, healthy, full and joyful life" (Hippocrates, 1936).

The ancient Greek philosopher Diogenes, who was concerned about the excessive consumption of food by people who, in his words, "overate to the detriment of health", was of the same opinion about a healthy lifestyle, and was also confident that exercise helped to achieve success in life: "a habit achieved by frequent exercise made it easier for us to behave with integrity. You who strove for virtue must be healthy and strong in mind and body. No success in life was possible without exercise; it won everything" (Kondrashov, 2010; Physical activity).
So it should be borne in mind that even in antiquity, special attention was paid to the preservation of health, as a value, the basis of which should not be treatment but the prevention and prophylaxis of diseases through a healthy lifestyle, with a focus on regular physical activity.

The concept of "physical activity" refers to any bodily movement produced by skeletal muscles and requiring the expenditure of energy. At the present stage of development of society, insufficient physical activity is one of the main risk factors for death in the world, while its level is growing in many countries, which increases the burden of non-infectious diseases and affects the general health of the population. People who are not physically active enough have a $20 \%-30 \%$ higher risk of mortality compared to those who lead an active lifestyle. Every fourth adult man in the world is not physically active enough, and more than $80 \%$ of adolescents lack physical activity (Global action plan for the prevention and control of noncommunicable diseases).

Regular physical activity of the appropriate intensity has significant health benefits:

- improves the condition of the muscles, as well as the cardiac and respiratory systems;

- improves bone health and functional health;

- reduces the risk of developing hypertension, coronary heart disease, stroke, diabetes, various types of cancer (including breast and colon cancer), depression;

- reduces the risk of falls (fractures of the hip and spine, etc.);

- underlies energy metabolism and maintaining proper weight.

The problem of insufficient physical activity indicates that an active lifestyle is critical for health, but in our modern world this is an increasingly difficult task. Moreover, physical inactivity is not only a health problem, it also carries huge financial costs for health care and the cost of declining productivity.

Given that increasing in level of physical activity is a problem not only for individuals, but for the whole society, a multisectoral, integrated approach is needed to solve it, which will be focused on certain groups of the population, taking into account the peculiarities of culture.

The primary responsibility for preventing physical inactivity-related illnesses rests with the national government, which has a central role to play in these activities but engagement from all sectors of society, international cooperation and joint action are key elements of success.

The main goal of public policy should be to reduce the "burden" of morbidity, mortality and disability caused by preventable and controlled diseases through multisectoral collaboration and joint action at the national, regional and global levels. This will allow the population to achieve high standards of health, quality 
of life and productivity in every age group and will positively affect the social and economic development of society.

For organizational support aimed at preventing diseases by increasing the physical activity of the population, it is necessary to implement an actual sports policy for the development of society.

Considering the health benefits that the activities of organizations in the sports industry can bring, let us pay attention to the words of the well-known sports and public figure, the initiator of the organization of the modern Olympic Games, the French Baron Pierre de Coubertin in his "Ode of Sport", who believed that it was playing sports that helped people to fight diseases: "Oh sport! You are fertility! You are an obstacle in the way of pernicious ailments that initially threaten people. You are a mediator. You recommend to the suffering, the weak, the sick the best of medicines - Yourself. You are an example of your strong, healthy, stately, muscular, hardened, and not amenable to disease adherents, heal the desperate. You heat the blood. Make the heart beat faster. You cure ailments. You are the red line in the "Health Code". You say: "A healthy mind is in a healthy body!" He paid attention that playing sports should be the prevention of diseases and aimed at human health, and not at causing harm to it: "You contribute to the perfection of man as the most beautiful creation of nature. You are direction. You order to act according to the rules and requirements of hygiene. You hold back from excesses. You teach a person voluntarily, consciously, with conviction to act so that no higher achievements, no records are the result of overstrain, have effect on health" (Pierre de Coubertin, 1987).

Also, it is worth paying attention to the works of biologist, anatomist, anthropologist, physician, teacher Peter Lesgaft, who was the creator of the theoretical functional anatomy and scientific system of physical education. At the heart of his pedagogical system is the doctrine of the inseparability of spiritual and physical development of man. In his understanding, exercise is a means of both physical, and moral, and intellectual development of the individual. At the same time, it is very important that mental and physical activity should be in full accordance with each other: the whole. He believed that exercise should promote human health, not harm it: "The method of physical education, as well as mental, should not in any way reduce the activity of the body and weaken it - on the contrary, its gradualness and consistency in the application of physical exercises, it must promote the proper development of the body and its health" (Lesgaft, 1953).

Modern sports policy of many developed countries is based on the understanding that sport is a field of human activity that interests citizens and has great potential for their unification, regardless of age or social background (White Paper on Sport). At the same time, most people are engaged in sports and health activities in amateur structures. The development of professional sports is becoming increasingly important and equally contributes to the social role of sports. In addition to improving the health of citizens, sport has an educational dimension and performs a social, cultural, and recreational function.

Sport is a dynamic and fast-growing sector with an underestimated macroeconomic impact and can contribute to growth and job creation. It can serve as a tool for local and regional development, urban regeneration or rural development. Sport has synergies with tourism and can stimulate the modernization of infrastructure and the emergence of new partnerships to finance sports and entertainment facilities. In addition, the potential of sports movement, which contributes to the strengthening of physical activity, often remains underutilized and needs to be developed.

There is also an understanding that sport makes an important contribution to economic and social cohesion and more integrated societies. All people in the country must have access to sports. Therefore, it is necessary to take into account the specific needs of all groups and the special role that sport can play for young people, people with disabilities and people from less privileged backgrounds. Sport can also promote the integration of migrants and foreigners into society, as well as support intercultural dialogue.

However, sport faces new threats and challenges that have emerged in society: commercial pressure, exploitation of young athletes, doping, racism, violence, corruption, and money laundering.

Thus, doping is a threat to sports all over the world, undermining the principle of open and fair competition. This is a factor that lowers motivation in sports in general and exposes the professional to unnecessary pressure. This seriously affects the image of sports and poses a serious threat to the health of individuals. Corruption, money laundering and other forms of financial crime affect sports locally, nationally and internationally. Given the high degree of internationalization of the sector, corruption in the sports sector often has crossborder dimensions.

The state sports policy and the development of the sports industry should focus on human health, namely, on the prevention of diseases, which is based on the increase in the physical activity of the population. Therefore, the formation of sports policy is associated with the acceleration of the implementation of global, national physical activity and health, appropriate measures to promote the positive effect of increasing the level of physical activity of the population.

\section{Conclusions}

The state sports policy should include the following provisions: 
1. Adoption and application of guidelines on physical activity for health promotion.

2. Consideration of issue on establishing a multisectoral committee or similar body to provide strategic guidance and coordination.

3. Forming appropriate partnerships and engaging all stakeholders, including governments, academia, civil society and economic actors, to actively engage in promoting physical activity among people of all ages.

4. Developing, in collaboration with relevant sectors, policy interventions that promote physical activity in daily life, including through 'active mobility', outdoor activities, leisure and sports, such as:

- urban planning and transport policies at the national and regional levels aimed at increasing the accessibility, acceptability and safety of walking and cycling, creating appropriate infrastructure;

- increasing the volume and quality of physical education programs in educational institutions (from educational institutions for young children to higher education institutions), including ensuring the possibility of physical activity before, during and after official hours of classes;

- implementation of programs to support and promote the implementation of initiatives under the slogan "Physical activity for all", addressed to all age groups of the population;

- creation and preservation of the built and natural environment conducive to physical activity in schools, universities, enterprises, hospitals, in places where people live, with particular emphasis on creating infrastructure for active means of transportation (for example, for walking and cycling), outdoor activities and games and sports.

5. Carry out evidence-based publicity campaigns in the media, social media and at the community level and conduct public service announcements to educate the public about the benefits of physical activity, create incentives for physical activity and promote healthy behavior. To achieve maximum effectiveness and coverage, such campaigns should be carried out in conjunction with supportive measures targeting different populations and organized in specific locations and institutions.

6. Promoting the evaluation of actions directed at increase in physical activity for collecting actual evidence on the effectiveness and cost-effectiveness of taken actions.

7. Increase in budgetary allocations in accordance with national priorities and taking into account national conditions.

8. Finding ways and means to secure adequate, predictable and sustainable resources through domestic, bilateral, regional and multilateral channels, including traditional and voluntary innovative financing mechanisms.

9. Actively attracting investments at the national and international levels, strengthening the country's scientific potential and further stimulating the introduction of innovations in the sports industry.

At the global level, there is an understanding that a person can be healthy only with regular physical activity; one should accept this as an indisputable fact and bring it to the consciousness of every person as a truth. This task should be solved at the state level through the formation of an effective sports policy and the creation of innovative and investment conditions for the accelerated development of the sports industry. So it becomes clear that there is a need to form a modern paradigm of sports policy, which should be based on the ideology of a healthy person and a prosperous society. Undoubtedly, it is a healthy person who is the foundation of a strong, competitive and prosperous country.

\section{References:}

Sukharev, V. A., \& Diadichev, V. V. (2012). Pochemu sovremennomu estestvoznaniiu nuzhna novaia nauchnaia paradigma [Why modern natural science needs a new scientific paradigm]. Tavricheskii nauchnyi obozrevatel, vol. 12 , no. 7 , pp. 105-114.

Kirilenko, G. G., \& Shevtcov, E. V. (2010). Kratkii filosofskii slovar [A Brief Philosophical Dictionary]. Moscow: AST, Slovo. (in Russian)

Becker, G. S. (1975). Human Capital: A Theoretical and Empirical Analysis, with Special Reference to Education. New York: National Bureau of Economic Research: distributed by Columbia University Press. USA.

Mikhaileva, E. G. (2016). Problemy razvitiia chelovecheskogo kapitala v sotcialnom pole Ukrainy: organizatcionnyi aspekt [Problems of human capital development in the social field of Ukraine: organizational aspect]. Kharkiv: NUA "Miskdruk". (in Ukrainian)

Grossman, M. (1972). [On the Concept of Health Capital and the Demand for Health]. Journal of Political Economy. Chicago. USA.

Grossman, M. (2000). The Human Capital Model. Handbook of Health Economics. New York. USA.

Forrester, S. V., \& Verevkina, D.S. (2016). Kapital zdorovia kak sostavliaiushchaia chelovecheskogo kapitala v sovremennykh usloviiakh [Health capital as a component of human capital in modern conditions]. Naukovedenie: elektronnyi zhurnal [Science of Science: electronic journal], no. 6. Available at: https://naukovedenie.ru/ PDF/18EVN616.pdf (accessed 17 December 2020).

Diogenes Laërtius (1986). O zhizni, ucheniiakh i izrecheniiakh znamenitykh filosofov [About the life, teachings and sayings of famous philosophers]. Moscow: Mysl. (in Russian) 
Ushakova, E. V., Nalivaiko, N. V., \& Vorontcov, P. G. (2017). O ponimanii zdorovia v meditcinskom, pedagogicheskom, sotcialnom i fizkulturnom aspektakh [On the understanding of health in medical, pedagogical, social and physical aspects]. Zdorove cheloveka, teoriia $i$ metodika fizicheskoi kultury i sporta: nauchnyi zhurnal, vol. 4, no. 1, pp. 18-29.

Bagnovskaia, N. M. (2017). Zdorove otdelnogo cheloveka - sotcialno znachimyi faktor zdorovia natcii [The health of an individual is a socially significant factor in the health of a nation]. Zdorove i obrazovanie $v$ XXI veke: nauchnyi spetcializirovannyi zhurnal, no. 1, pp. 130-132.

Boiko, Yu. S. (2014). Maukovyi analiz katehorii "zdorovia" ta "zdorovyi sposib zhyttia" z pozytsii pedahohichnoi aksiologii [Scientific analysis of the category of "health" and "healthy way of life" from the position of pedagogical axiology]. Psykholoho-pedahohichni problemy silskoi shkoly: zb. nauk. prats Umanskoho derzhavnoho pedahohichnoho universytetu imeni Pavla Tychyny, no. 50, pp. 63-71.

Zahalna teoriia zdorovia ta zdoroviazberezhennia (2017). [General theory of health that health care]. Kharkiv.

Statut Vsesvitnoi orhanizatsii okhorony zdorovia [Charter of the World Health Organization]. Database of All-Holy Organization of Health Protection. Available at: http://apps.who.int/gb/bd/PDF/bd48/basicdocuments-48th-edition-ru.pdf?ua $=1 \#$ page $=9$ (accessed 17 December 2020).

Health promotion and healthy lifestyles: Report by the Secretariat. Database World Health Organization. Available at: http://apps.who.int/iris/bitstream/handle/10665/20087/A57_11-en.pdf?sequence=1\&is Allowed=y (accessed 17 December 2020).

Global action plan for the prevention and control of noncommunicable diseases. Database World Health Organization. Available at: http://apps.who.int/iris/bitstream/handle/10665/94384/9789241506236_eng.pdf; jsessionid=BA6144FADA7776C2CF48C70EBBAAF0BB? sequence=1 (accessed 17 December 2020).

Hippocrates (1936). Izbrannye knigi [Selected books]. Moscow.

Kondrashov, A. P. (2010). Luchshie aforizmy velikikh liudei. Formula uspekha. Moskva [The best aphorisms of great people. The formula for success]. Moscow: RIPOL Klassik. (in Russian)

Physical activity. Database World Health Organization. Available at: http://www.who.int/mediacentre/factsheets/ fs385/en/ (accessed 17 December 2020).

Global action plan for the prevention and control of noncommunicable diseases. Database World Health Organization. Available at: http://apps.who.int/iris/bitstream/handle/10665/94384/9789241506236_eng.pdf; jsessionid=BA6144FADA7776C2CF48C70EBBAAF0BB? sequence=1 (accessed 17 December 2020).

Pierre de Coubertin (1987). Oda sportu [Ode to sport]. Moscow: Fizkultura i sport. (in Russian)

Lesgaft, P. F. (1953). Sobranie pedagogicheskikh sochinenii [Collected pedagogical works]. Moscow: Fizkultura i sport. (in Russian)

White Paper on Sport. Database European Union Law. Available at: http://eur-lex.europa.eu/legal-content/EN/ TXT/?qid=1389190214279\&uri=CELEX:52007DC0391 (accessed 17 December 2020). 